\title{
SOCIAL ENVIRONMENT IN SUPPORTING GIFTED STUDENTS' ACADEMIC ACHIEVEMENT
}

\author{
Dianti Endang Kusumawardhani \\ Fakultas Psikologi, Universitas Indonesia, Depok \\ *Email: dianti.kusumawardhani@ui.ac.id
}

\begin{abstract}
The implementation of acceleration program for the gifted students was problematic and has been dismissed by Indonesian Government in 2014. 240 first year students from three high schools in Jakarta participated in this study. The study focused on the social environment that is projected in accelerated and regular classrooms. Type of Classrooms is associated with Accelerated learning. Path analysis model was used to develop the relationships between latent and manifest variables. This study employed PLSPATH program to analyse the data. The results showed accelerated learning is positively related to Self-Regulated Learning in Biology but there is only a very weak relation in Mathematics. Accelerated learning positively and marginally related to Self-Efficacy in Biology, but negatively and marginally related to Mathematics Self-Efficacy. There is a significant relationship between Accelerated learning and Achievement in both Mathematics and Biology.
\end{abstract}

Keywords: social environment, gifted student, academic achievement

\begin{abstract}
Abstrak
Terdapat masalah dalam pelaksanaan program akselerasi untuk siswa berbakat dan program ini telah dihentikan oleh Pemerintah Indonesia pada tahun 2014. Sebanyak 240 siswa tahun pertama dari tiga sekolah menengah di Jakarta berpartisipasi dalam penelitian ini. Studi ini berfokus pada lingkungan sosial yang digambarkan melalui ruang kelas akselerasi dan reguler. Studi menguji keterkaitan antara jenis ruang kelas dengan pembelajaran jenis akselerasi. Model analisis jalur digunakan untuk mengembangkan hubungan antara variabel laten dan manifes. Analisis statistik pada penelitian ini menggunakan program PLSPATH. Hasil penelitian menunjukkan pembelajaran akselerasi berhubungan positif dengan Self-Regulated Learning pada mata pelajaran Biologi, tetapi hubungan ini sangat lemah pada mata pelajaran Matematika. Pembelajaran akselerasi berhubungan secara positif dan kecil dengan efikasi diri pada Biologi, tetapi berhubungan secara negatif dan kecil dengan efikasi diri Matematika. Ada hubungan yang signifikan antara pembelajaran akselerasi dengan prestasi akademik pada Matematika dan Biologi.
\end{abstract}

Kata Kunci: lingkungan sosial, siswa berbakat, prestasi akademik

\section{Introduction}

Acceleration program for gifted students in Indonesia has been dismissed since 2014. The Indonesian government's approval to conduct acceleration program itself began in the 2000/2001 academic year after the 1989 Second Law on the
National Education system (Sistem Pendidikan Nasional, 1989) Act 8(1) published. The national law gave attention to students with special learning needs who had learning difficulties because of suffering for physical or mental handicap. The program for the gifted was to shortened 
the period of study time from three to two years at middle school level, and from six to four years at elementary school level so students in accelerated classrooms had more tasks to be completed than as a consequence of the shortened period of study time (Kompas Cetak, 2004). van Tiel proposed that a program for gifted students should consider a kind of access for gifted students to obtain more help from teachers, such as support staff, guidance and counselling staff, therapeutic sessions, and remedial teaching (Van Tiel, 2007), and in line with Kusumawardhani (2000) that students viewed learning as a duty of the teachers. The shortened study time brought some problems to the gifted students and being in a learner-centred classroom put them to be more self-regulated learner and need social assistance from significance others.

Hadis (Kompas, 30 May 2002) noted gifted students faced more social and emotional problems than regular students. She said that the complicatedness faced by gifted students were social isolated by peers and boringness because of their intellectual capacities. She observed that gifted students were tending not to show their high abilities in front of their peers in order to get the likes from them. As an example, problems for being in the acceleration program were also experienced by the Indonesian mother whose daughter found difficulties to fit into her classmates (Kompas, 15 August 2004). Her daughter had joined an acceleration program since primary school, junior secondary school, and then in high school. She was three or four years younger than her classmates. She upset when one of her classmates did not tell the truth to another teacher that the teacher was absent instead of tell that their teacher was not coming. In this case, the students' social skill development should be considered as an important matter when the institution decided to run an acceleration program. It was also in line with Schneider, Clegg,
Byrne, Ledingham, and Crombie (1989) who made suggestion that in developing program for the gifted students to some extent it would be necessary to facilitate their cognitive as well as their social development.

The dismissal of acceleration program has been implemented by Indonesian government, and it is interesting to look back what personal and social factors contributed to the use of selfregulated learning strategies to reach students' academic achievement. One reason the government dismissed the acceleration program, said Achmad Jazidie (Dirjen Pendidikan Menengah Kementerian Pendidikan dan Kebudyaan), was in order to assuage the discrimination between the brighter students and the average students (Republika, 14 October 2009). Based on experiences as the coordinator of acceleration program in SMA Negeri 3 Semarang, Abdullah Sigimin said that being in an accelerated class had any impacts on students' social factor (Antara News, 5 July 2010). He found that accelerated students focused more on their academic tasks and spent less time to get social experiences. Furthermore, from his observation he noticed that accelerated students perceived themselves to have higher grade of ability than regular students, and then formed exclusive groups among students in the school. This study was conducted in two different classrooms as the environmental factor, that was, accelerated and regular classrooms in Biology and Mathematics subjects. These two subjects have more different characteristics, that is, subject students need more memorizing efforts to master Biology subjects than Mathematics subject.

Social Cognitive Approach on Self-Regulated Learning. The Bandura's Triadic Theory of Social Cognition is a theoretical perspective of self-regulated learning which focused on three factors; personal, behavioural, and environmental factors. Bandura's triadic formulation (Bandura, 1986) described students' self- 
regulated learning was a function of academic context, personal efforts, and behavioural performance (Zimmerman \& Martinez-Pons, 1990). Students' personal efforts covered what learning strategies were picked up by students. Schunk (Zimmerman, 2001, p.19) proposed that students' learning efforts were influenced by environmental and behavioural events in a reciprocal way not only on personal factor. This reciprocal relation is presented in Figure 1.

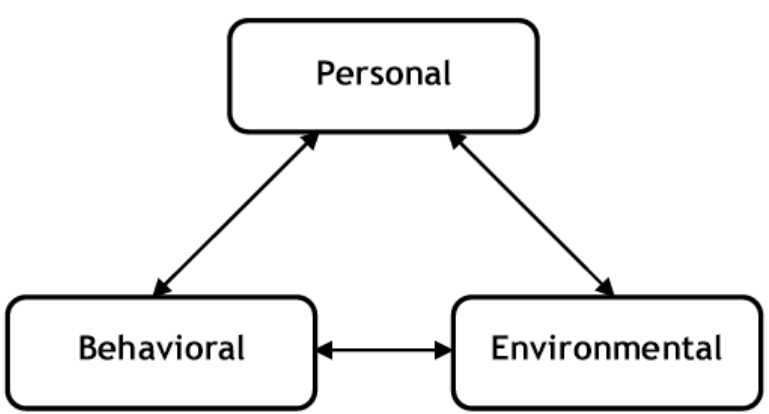

Figure 1: Bandura's Model of Reciprocal Determinism (Bandura, 1986)

Bandura (1997) proposed that people were respondents who gave response actively to the environmental stimuli. For that reason, the learners could adopt information from observing other people's behaviour, and then decided behaviours to adopt and enact (Gredler, 2001). Social cognitive theory took more attention on person's expectations about the consequences of behaviour. It concerns of what a person believes about what would happen in the future, not what can happen in the past. For example, a student might expect no reward for working hard on a particular task, if the student thought a teacher was a very hard task marker (Bandura, 1997).

In social cognitive theory there are key factors that affect behaviour (Bandura, 1997), namely, vicarious learning, personal agency and self-efficacy. 'Vicarious learning' is the observation process of model behaviour got reinforce for the behaviour (Bandura, 1997). In a social cognitive approach, people are perceived as active agents in doing their activities and deciding which strategies to make an assignment completed (Bandura, 1997). Social cognitive theory triggered people to create various strategies in directing their own behaviour toward rewards they perceived to receive.

Self-Regulated Learning Strategies. A method to accomplish a task is called a strategy and it is used steadily in a specific condition, otherwise a student may look for a new strategy to be activated (Kirby, 1984). In the search for personal learning goals, students use various learning strategies (Schloemer \& Brenan, 2006). Zimmerman and Martinez-Pons (1986) developed the Self-Regulated Learning Interview Schedule (SRLIS) to explore the Self-Regulated Learning strategies of high school students. They proposed 14 Self-Regulated Learning strategies, that is, (1) Self-evaluation, (2) Organizing and transforming, (3) Goalsetting and planning, (4) Seeking information, (5) Keeping records and monitoring, (6) Environmental structuring, (7) Selfconsequences, (8) Rehearsing and memorizing, (9-11) Seeking social assistance, (12-14) Reviewing records. The 14 SRL strategies imply student works by himself/herself and seeks for assistance. From the 14 SRL strategies, the seeking social assistance is the strategy elicited by students to ask for a help from others.

Deciding when to seek for social assistance is a usefulness skill for students to self-regulate their behaviour (Stipek, 2002). After a student makes a decision to seek help, he or she articulates what part the he or she understands and does not understand. Students may look for help when they believe academic difficulties are not due to low aptitude or other controllable factors, and when they believe performance is likely to improve with more effort (Graham, 1991).

Self-Regulated Learning questionnaires developed from the $14 \mathrm{SRL}$ strategies described by Zimmerman and Martinez-Pons (1986) and Winne and Perry (2000), and the Motivated Strategies for Learning Questionnaire deve 
loped by Pintrich and de Groot (1990) were available for use in this study.

Academic Self-Efficacy. To have a basic foundation of behaviour and motivation provided by students, researchers and practitioners in the field of education relied on one of the strong beliefs, that was, self-perception and students' belief play a key role in learning and influence achievement (Bong \& Skaalvik, 2003). The term of self-perception is linked to the various attributions and beliefs that students assign to themselves. It has been a common argument that self-confidence is seen essential to success in any academic area (Bandura, 1997). Thus, the centrality of self-competence perception takes an important part in students' self-efficacy beliefs (Bong \& Skaalvik, 2003).

The notion of self-efficacy is similar but not the same as the notion of selfconcept and expectancy (Bong \& Skaalvik, 2003) and expectancy (Wood \& Locke, 1987). Woolfolk (1998) formulated selfefficacy as a person's sense of being able to accomplish and about personal competence beliefs in a particular task. It can be concluded that perceived self-efficacy is an appraisal of students' articulation of confidence to perform specific tasks.

Self-efficacy gives explanation of the function of self in school setting, and both are based on students' previous achievement. Students with different selfbeliefs perform different levels of cognitive, social, and emotional involvement in school. According to Lorsbach and Jinks (1999), academic self-efficacy belief termed as the representation of students' expectations and convictions about their competence. Academic self-efficacy refers to students' self-efficacy belief to master toward academic activities (Bong \& Skaalvik, 2003; Bandura, 1995). It can be concluded that academic self-efficacy can be defined as students' expressions of confidence in student's perceived ability to organize actions to attain specific results in academic setting.
In this study, there were two process variables, that is, self-regulated learning and self-efficacy, hypothesised to influence learning. It was hypothesised that SelfRegulated Learning strategies influenced Self-Efficacy tactics in a way that was consistent with strategies influencing tacItics.

\section{Research Methods}

Participants. Participants were a group of individuals, classrooms, and schools with some common defining characteristics and drawn from appropriate target population. Participants were students in Indonesian high schools that conducted accelerated learning and then the groups of students in the selected classrooms formed the sample in this intervention study.

There were three participant schools, that is, a government school, a general private school, and an Islamic school. 240 first year high school students (46 accelerated and 194 regular students) at Grade 10 level were listed as participants. Within each school, the teachers selected three classrooms, that is, one classroom involved in an accelerated program and the other two classrooms involved in a regular program. Classrooms and the students were divided into two groups, that is, the Treatment Group and Non-Treatment Group. The Treatment Group was students from three accelerated classrooms and three regular classrooms from three participating schools. The NonTreatment Group was students from regular classrooms. This study involved a partly randomised model that involved some random assignment of classrooms and their students to the Treatment Groups.

In this study, there was no student in accelerated classrooms assigned to the Non Treatment group because of the limited number of accelerated students. As the consequence, the sample's design was unbalanced and according to Kish (1987) this was a common practice in research with special populations (Kline, 


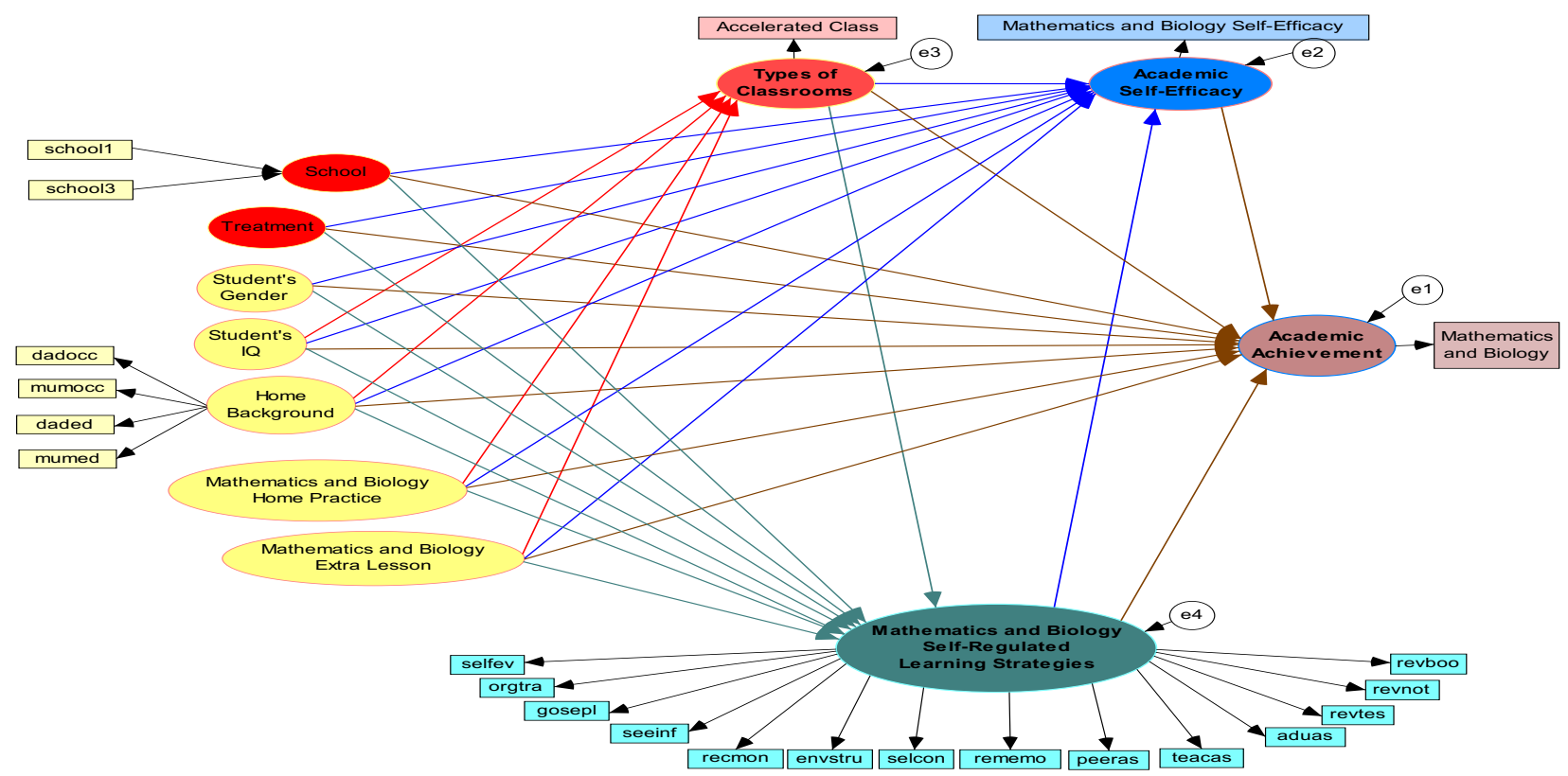

Figure 1. An initial model detailing the relationships among accelerated students and regular students, gender differences, IQ, home background, home practice, extra lessons, the 14 Self-Regulated Learning strategies, Academic Self-Efficacy (Mathematics and Biology), and Academic Achievement (Mathematics and Biology)

2005; p.21) and in any case unequal group size was a problem depended on the research substance (Kline, 2005).

Research Models. The path analysis model was developed to undertake an exploratory study in order to examine the relationships between each of the manifest variables (MVs) and its respective latent variable (LV), as well as to investigate the relationships between the explanatory latent variables and the other dependent latent variables (LVs). There are 30 MVs and $12 \mathrm{LVs}$ involved in the path model that can be seen in Figure 1. The hypothesized path model of the study was examined at the student level and the variables involved are given in Table 1.

Procedure. This study was within social-cognitive learning theory and participated by students (boys and girls) at Grade 10 high school who were drawn from the three participating schools with students of very different abilities, aptitudes, and interests. There were two subjects, Mathematics and Biology, within the Indonesian National Curriculum. Each school had its own achievement tests that were differed between schools. Information was retrieved by researcher on student abilities using the Cattell's Culture
Fair Intelligence Test Scale 3 Form A (adapted and normed by the Faculty of Psychology, Universitas Indonesia, 1996) that was administered to all students. Information on student aptitude was taken using a prior achievement test, while information on student interests was collected on expected higher education, home practice, extra lessons, and parental occupation and education.

The obtaining of information involved the administration of: (a) Self-Regulated Learning (SRL) Questionnaire, (b) SelfEfficacy (SE) Questionnaire, (c) Achievement tests in Mathematics and Biology. The design undertook to conduct the study in a setting that was as close as possible to normal classroom and school environments.

The SRL Questionnaire being used in this study developed from the $14 \mathrm{SRL}$ strategies established by Zimmerman and Martinez-Ponz (1986), Winne and Perry (2000), and the Motivated Strategies for Learning Questionnaire established by Pintrich and de Groot (1990). Example of the SRL Questionnaire was "I discuss how to finish assignments with friends". 
Table 1. Variables in the Study

\begin{tabular}{|c|c|c|c|c|c|c|}
\hline No & Variables & $\begin{array}{l}\text { Latent } \\
\text { Variables }\end{array}$ & Description & $\begin{array}{l}\text { Manifest } \\
\text { Variables }\end{array}$ & Description & Coding \\
\hline \multirow[t]{3}{*}{1} & \multirow{3}{*}{$\begin{array}{l}\text { Control } \\
\text { Variable }\end{array}$} & \multirow[t]{3}{*}{$\mathrm{SCHOOL}$} & \multirow[t]{3}{*}{ School } & SCHOOL 1 & School 1 & 0,1 \\
\hline & & & & SCHOOL 2 & School 2 & 0,1 \\
\hline & & & & SCHOOL 3 & School 3 & 0,1 \\
\hline 2 & $\begin{array}{l}\text { Control } \\
\text { Variable }\end{array}$ & TREATM & Treatment & TREAT & Treatment & 0,1 \\
\hline 3 & $\begin{array}{l}\text { Control } \\
\text { Variable }\end{array}$ & CLASSRMS & Classroom & CLASSRM & Classroom & 0,1 \\
\hline 4 & $\begin{array}{l}\text { Control } \\
\text { Variable }\end{array}$ & SGENDER & Gender & GENDER & Gender & 0,1 \\
\hline 5 & $\begin{array}{l}\text { Control } \\
\text { Variable }\end{array}$ & IQS & $\begin{array}{l}\text { Intelligence } \\
\text { Quotient }\end{array}$ & IQ & Intelligent Qoutient & $81-144$ \\
\hline \multirow[t]{4}{*}{6} & \multirow{4}{*}{$\begin{array}{l}\text { Antecedent } \\
\text { Variable }\end{array}$} & \multirow[t]{4}{*}{ HOMBACK } & \multirow{4}{*}{$\begin{array}{l}\text { Home } \\
\text { Background }\end{array}$} & DADOCC & Father's Occupation & $0-9$ \\
\hline & & & & MUMOCC & Mother's Occipation & $0-9$ \\
\hline & & & & DADED & Father's Education & $0-7$ \\
\hline & & & & MUMED & Mather's Education & $0-7$ \\
\hline 7 & $\begin{array}{l}\text { Antecedent } \\
\text { Variable }\end{array}$ & HOMPRAC & $\begin{array}{l}\text { Home } \\
\text { Practice }\end{array}$ & HOMPRAC & Home Practice & $0-4$ \\
\hline 8 & $\begin{array}{l}\text { Antecedent } \\
\text { Variable }\end{array}$ & EXTLESS & $\begin{array}{l}\text { Extra } \\
\text { Lessons }\end{array}$ & EXTLESS & Extra Lessons & $0-2$ \\
\hline 9 & $\begin{array}{l}\text { Antecedent } \\
\text { Variable }\end{array}$ & EXPED & $\begin{array}{l}\text { Expected } \\
\text { Higher } \\
\text { Education }\end{array}$ & EXPED & Expected Higher Education & $0-4$ \\
\hline \multirow[t]{14}{*}{10} & \multirow{14}{*}{$\begin{array}{l}\text { Process } \\
\text { Variable } \\
\text { (Mediating } \\
\text { Criterion) }\end{array}$} & \multirow[t]{14}{*}{ SRL } & \multirow{14}{*}{$\begin{array}{l}\text { Self- } \\
\text { Regulated } \\
\text { Learning } \\
\text { Strategies }\end{array}$} & SELFEV & Self-Evaluation & $1-4$ \\
\hline & & & & ORGTRA & Organising \& Transforming & $1-4$ \\
\hline & & & & GOSEPL & Goal-setting \& Planning & $1-4$ \\
\hline & & & & SEEINF & Seeking Information & $1-4$ \\
\hline & & & & RECMON & Recording \& monitoring & $1-4$ \\
\hline & & & & ENVSTRU & Environmental Structuring & $1-4$ \\
\hline & & & & SELCON & Self-Consequences & $1-4$ \\
\hline & & & & REMEMO & Rehearsing \& Memorising & $1-4$ \\
\hline & & & & PEERAS & $\begin{array}{l}\text { Seeking for Peers' } \\
\text { Assistance }\end{array}$ & $1-4$ \\
\hline & & & & TEACAS & $\begin{array}{l}\text { Seeking for Teachers' } \\
\text { Assistance }\end{array}$ & $1-4$ \\
\hline & & & & ADUAS & $\begin{array}{l}\text { Seeking for Adults' } \\
\text { Assistance }\end{array}$ & $1-4$ \\
\hline & & & & \multirow{3}{*}{$\begin{array}{l}\text { REVTES } \\
\text { REVNOT } \\
\text { REBOO }\end{array}$} & \multirow{3}{*}{$\begin{array}{l}\text { Reviewing Test } \\
\text { Reviewing Notes } \\
\text { Reviewing Textbooks }\end{array}$} & $1-4$ \\
\hline & & & & & & $1-4$ \\
\hline & & & & & & $1-4$ \\
\hline 11 & $\begin{array}{l}\text { Process } \\
\text { Variable } \\
\text { (Mediating } \\
\text { Criterion) }\end{array}$ & SE & Self-Efficacy & SE & Self-Efficacy & $1-4$ \\
\hline 12 & $\begin{array}{l}\text { Outcome } \\
\text { Variable } \\
\text { (Criterion) }\end{array}$ & $\mathrm{ACH}$ & Achievement & $\mathrm{ACH}$ & Achievement & $33-99$ \\
\hline
\end{tabular}


The SE Questionnaire was developed from Bandura's Self-Efficacy theory (Bandura, 1986), Guide for constructing SelfEfficacy Scales (Bandura, in press), the General Self-Efficacy Scale (Sherer et al, 1982) and the Motivated Strategies for Learning Questionnaire (Pintrich \& De Groot, 1990). Example of the SRL Questionnaire was "I can get myself to study math (or biology) when there are other interesting things to do". For the SelfRegulated Learning Questionnaire, the scales consisted the categories of 'never', 'sometimes', 'often', and 'all of the time'. For the Self-Efficacy Questionnaires, the scales consisted the categories of 'never true of me', 'sometimes true of me', 'often true of me', and 'always true of me'.

Analysis. The main variables in this study are Self-Regulated Learning Strategy, Self-Efficacy in Mathematics or/and Biology, and Academic Achievement. Selfregulated learning is a term used to specify the essentials of successful learners and self-regulated learners can be defined as active participants in the learning process. As Bandura (1995) stated, students' academic self-efficacy involved students' belief in their capabilities to master academic activities. In this study academic achievement scores of mathematics and biology were drawn from tests conducted by schools. In the proposed model, all possible relationships among variables are hypothesised for an exploratory study. This study used path analysis as a method for studying direct and indirect effects of variables hypothesized as influencing the criterion variables (Pedhazur, 1997, p.769). The PLSPATH program is used to test the hypothesised model and to assess whether it can be rejected or provisionally accepted as adequate. In a model, a number of manifest or observed variables (MV) are grouped together to form a latent variable so that the number of paths in the model can be reduced to a manageable number. Path analysis was developed by Sewall Wright as a method for studying direct and indirect effects of variables hypothesised as causes of variables treated as effects (Pedhazur, 1997. p.769). Keeves (1988, p.724) suggested that the use of path analysis can be employed "to shift from verbal statements of a complex set of interrelationships between variables to more precise mathematical ones and to estimate the magnitudes of the causal links involved". In addition, use of path analysis can show direct and indirect effects because the effects of more distal variables are frequently mediated through other more proximal variables.

The PLS program used in the study to conduct path analyses is PLSPATH version 3.01 that was developed by Sellin (1989). The analyses are based on the partial least squares procedure, with latent constructs measured by multiple indicators (Wold, 1982; Sellin, 1995). Sellin (1995) argued that PLS is flexible and powerful, as it can deal with large data sets as well as small data sets, and is simple in technical operation and has no requirement for distributional assumptions. However, PLSPATH does not allow for the estimation of measurement errors of MVs and for the inter-correlations between the errors associated with the MVs.

The relationships among variables in PLSPATH models are developed through two sets of linear equations, namely the inner model and the outer model (Sellin, 1995). The inner model is defined as "the relationships between unobserved or latent variables (LVs)", and the outer model is defined as "the relationships between LVs and their associated observed or manifest variables (MVs)" (Sellin, 1995, p.257). The inner model represents a causal relationship between LVs in the path model by a unidirectional arrow from the determining variable to the variable dependent on it (Sellin, 1995). Keeves (1998) stated that there are three kinds of variables to be recognised in the path models by observing the unidirectional arrows pointing towards the variable. The three kinds of variables are referred to as 
Table 2. IQ Scores

\begin{tabular}{clrr}
\hline School & \multicolumn{1}{c}{ Group } & Mean & \multicolumn{1}{c}{ SD } \\
\hline $1,2,3$ & All participants & 112,15 & 13,37 \\
\hline \multirow{2}{*}{1} & Accelerated - Experiment Group & 113,71 & 14,60 \\
& Reguler - Experiment Group & 110,67 & 13,91 \\
& Reguler - Non Experiment Group & 111,03 & 10,39 \\
\hline \multirow{2}{*}{2} & Accelerated - Experiment Group & 123,70 & 11,61 \\
& Reguler - Experiment Group & 94,94 & 8,41 \\
& Reguler - Non Experiment Group & 107,00 & 11,98 \\
\hline \multirow{2}{*}{3} & Accelerated - Experiment Group & 122,93 & 15,33 \\
& Reguler - Experiment Group & 116,54 & 9,56 \\
& Reguler - Non Experiment Group & 113,03 & 11,74 \\
\hline
\end{tabular}

exogenous variables, endogenous variables, and the outcome latent variable. Determining variables that do not depend on other variables are referred to as exogenous variables and are indicated by no unidirectional arrow pointing towards the variable. Endogenous variables are defined as variables that are dependent on other variables. Endogenous variables are indicated by one or more unidirectional arrows pointing towards the variable. In addition, the outcome latent variable is the variable that is dependent only on other variables.

\section{Results}

The IQ score of all participants presented in Table 2. As seen in the Table 2, the IQ scores from School 1 were at the same range for all participants. Accelerated participants from School 2 and 3 were at the different range from participants from regular classroom.

Sellin (1989) stated that the relationships between the LVs are estimated from the inner model results. In the PLSPATH program, the strength of relationship between LVs is given by four indices from the inner model results, that is, beta coefficient, the zero-order or product-moment correlation between a given predictor LV and the dependent LV, tolerance index as the squared multiple correlation between a predictor LV and the set of remaining predictor LVs involved in a given inner model equation, R-square value. The simple random sample standard error for a correlation coefficient with $\mathrm{N}=233$ is:

$$
\text { se }=\frac{1}{\sqrt{N}}=0.07
$$

This section discusses the beta coefficients and the R-square values for the inner model results. The tolerance indexes of the LVs are below the critical value of 0.50 . The R-square values, direct and indirect effects from the inner model results are presented in Table 3 .

This following section provides information about the students prior to the intervention. The information of variable TREATMENT should be included in order to provide the baseline data in initial condition.

The use of Self-Regulated Learning strategies in Mathematics is likely to be influenced by how frequently students practise Mathematics outside school hours or at home. Membership of the Treatment Group is not a significant predictor of Self-Regulated Learning. There is no indication that, when learning Mathematics, students in Non-Treatment Groups are using Self-Regulated Learning strategies with different frequency than those in Treatment Group. However, the variable TREAT is included in the regression model because it is a control variable, and it is necessary to control for any effects that it may have in the estimation of the effects of other factors. 
Table 3. R-square, Direct (ß) and Indirect Effects (i) for the Initial Condition for the Mathematics and Biology Models

\begin{tabular}{|c|c|c|c|c|}
\hline \multirow[b]{2}{*}{ Variable $^{a}$} & \multicolumn{2}{|c|}{$\begin{array}{l}\text { Mathematics } \\
\text { Initial Condition }\end{array}$} & \multicolumn{2}{|c|}{$\begin{array}{c}\text { Biology } \\
\text { Initial Condition }\end{array}$} \\
\hline & Direct $(ß)$ & Indirect (i) & Direct (ß) & Indirect (i) \\
\hline CLASSRMS & \multicolumn{2}{|c|}{ R-square $=0.20$} & \multicolumn{2}{|c|}{ R-square $=0.20$} \\
\hline $\mathrm{IQ}$ & $0.23^{*}$ & - & $0.21^{*}$ & - \\
\hline HOMBACK & $-0.26^{*}$ & - & $-0.31^{*}$ & - \\
\hline HOMPRAC & $0.18^{*}$ & - & $0.25^{*}$ & - \\
\hline EXTLESS & $-0.21^{*}$ & - & $-0.15^{\star}$ & - \\
\hline SRL & \multicolumn{2}{|c|}{ R-square $=0.10$} & \multicolumn{2}{|c|}{ R-square $=0.10$} \\
\hline $\mathrm{SCHOOL}$ & $0.19^{*}$ & - & $-0.13^{\wedge}$ & - \\
\hline TREATM & -0.03 & - & -0.02 & - \\
\hline GENDER & - & - & $-0.16^{*}$ & - \\
\hline $\mathrm{IQ}$ & - & 0.01 & $-0.16^{*}$ & 0.03 \\
\hline HOMBACK & - & -0.01 & - & -0.05 \\
\hline HOMPRAC & $0.22^{*}$ & 0.01 & $0.25^{*}$ & 0.04 \\
\hline EXTLESS & - & -0.01 & - & -0.03 \\
\hline CLASSRMS & 0.05 & - & $0.16^{*}$ & - \\
\hline SE & \multicolumn{2}{|c|}{ R-square $=0.31$} & \multicolumn{2}{|c|}{ R-square $=0.31$} \\
\hline SCHOOL & $0.25^{*}$ & 0.08 & $-0.27^{*}$ & -0.07 \\
\hline TREATM & $0.14^{*}$ & -0.01 & $0.10^{\wedge}$ & -0.01 \\
\hline GENDER & $0.12^{\wedge}$ & - & - & -0.09 \\
\hline $\mathrm{IQ}$ & $0.23^{*}$ & -0.03 & - & -0.04 \\
\hline HOMBACK & - & 0.03 & - & -0.07 \\
\hline HOMPRAC & - & 0.07 & - & 0.19 \\
\hline EXTLESS & - & 0.02 & - & -0.03 \\
\hline CLASSRMS & $-0.13^{\wedge}$ & 0.02 & $0.12^{\wedge}$ & 0.09 \\
\hline $\mathrm{SRL}$ & $0.42^{*}$ & - & $0.54^{*}$ & - \\
\hline $\mathrm{ACH}$ & \multicolumn{2}{|c|}{ R-square $=0.62$} & \multicolumn{2}{|c|}{ R-square $=0.62$} \\
\hline SCHOOL & $0.61^{*}$ & 0.07 & $0.61^{*}$ & - \\
\hline TREATM & -0.06 & 0.03 & -0.05 & - \\
\hline GENDER & - & 0.03 & - & - \\
\hline $\mathrm{IQ}$ & - & 0.09 & $0.21^{*}$ & 0.06 \\
\hline HOMBACK & $-0.14^{*}$ & -0.05 & - & -0.08 \\
\hline HOMPRAC & - & 0.05 & - & 0.07 \\
\hline EXTLESS & - & -0.04 & - & -0.04 \\
\hline CLASSRMS & $0.20^{*}$ & -0.02 & $0.26^{*}$ & - \\
\hline SRL & - & 0.09 & - & - \\
\hline SE & $0.22^{*}$ & - & - & - \\
\hline Mean R-square & 6r- & 0.31 & & 0.31 \\
\hline
\end{tabular}

It is seen in Table 3 that GENDER, $I Q$, HOMPRAC and CLASSRMS are significantly related to BSRL and there is also a marginally significant influence from SCHOOL. There are differences between the role of SCHOOL in MSRL and
BSRL. The role of SCHOOL in MSRL (Mathematics Self-Regulated Learning) is positive and significant, while in BSRL (Biology Self-Regulated Learning) the role of SCHOOL is negative and marginally significant. 
There are also some other differences between the MSRL and BSRL regression equations, with GENDER and $I Q$, being significantly related to $B S R L$ (Biology Self-Regulated Learning) and but not for MSRL (Mathematics Self-Regulated Learning). In this case, girls are more likely to apply Self-Regulated Learning strategies in their learning in Biology. In addition, students with higher IQ are more likely not to apply Self-Regulated Learning strategies in their learning of Biology. Membership of the Treatment Group is not significantly related to the use of Self-Regulated Learning strategies, and there are only small differences between the treatment and the control groups in this respect.

Self-Efficacy at Initial Condition. Table 3 presents results that show SCHOOL, TREATM, IQ and MSRL (Mathematics Self-Regulated Learning) are significantly related to MSE (Mathematics Self-Efficacy). GENDER and CLASSRMS are marginally significant independent variables. SCHOOL1 has a greater influence on the level of Self-Efficacy in Mathematics than SCHOOL2 and SCHOOL3 but not in Biology. Students in SCHOOL1 have a higher level of Self-Efficacy in Mathematics than the students in SCHOOL2 and SCHOOL3 but a lower level of Self-Efficacy in Biology after other factors are taken into consideration. Furthermore, students with a higher level of Mathematics Self-Efficacy are more likely to be: (a) students in Treatment Groups, (b) with higher $I Q$, and (c) using SelfRegulated Learning strategies in Mathematics learning, and (d) boys. In addition, students in accelerated classrooms express a lower level of Self-Efficacy in Mathematics learning than do students in non-accelerated classrooms. However, this effect is considered to be only marginally significant, but may be of some practical importance.

Table 3 also shows that SCHOOL and BSRL (Biology Self-Regulated Learning) are significantly related to BSE (Biology Self-Efficacy). TREATM and CLASS-
RMS are marginally significant independent variables. The role of $\mathrm{SCHOOL}$ and SRL are not the same for both BSE (Biology Self-Efficacy) and MSE (Mathematics Self-Efficacy). SCHOOL1 has a greater influence on a higher level of SelfEfficacy in Mathematics than SCHOOL2 and SCHOOL3 but not in Biology, where a lower level of Self-Efficacy is involved. In other words, students in SCHOOL1 have a higher level of Self-Efficacy in Mathematics, but not in Biology, than do the students in SCHOOL2 and SCHOOL3. In this analysis from the information at Time 1 in forming the variable SCHOOL, SCHOOL1 has a positive loading, SCHOOL2 has a zero loading, and SCHOOL3 has a negative loading. While in table 3 the variable SCHOOL has a positive weight for Mathematics and negative weight for Biology at Time 1 .

Moreover, students with a higher level of use of Self-Regulated Learning strategies are more likely to express a higher level of Self-Efficacy in both Mathematics and Biology. There is considerable difference between the influence of CLASSRMS on BSE (Biology SelfEfficacy) and MSE (Mathematics SelfEfficacy). The path coefficients for classrooms are marginally significant and negative for Mathematics and marginally significant and positive for Biology. Thus students in Accelerated classrooms are more likely to have higher self-efficacy for learning Biology, but lower self-efficacy for learning Mathematics.

Academic Achievement at Initial Condition. The results in Table 3 indicate that initially there are four variables that are significantly related to Mathematics Achievement: SCHOOL, HOMBACK, CLASSRMS and MSE (Mathematics SelfEfficacy). It is seen that students in SCHOOL1 perform better in Mathematics Achievement than students in SCHOOL2 and SCHOOL3. Students in accelerated classrooms achieve better in Mathematics than students in regular classrooms. High self-efficacy is also associated with better scores in the Mathematics tests. 
Table 4. Regression Coefficients for Student Characteristics (Gender, IQ, Home Background, Home Practice, and Extra Lessons) on Type of Classrooms, SelfRegulated Learning (SRL), Self-Efficacy, and Academic Achievement at Initial Condition

\begin{tabular}{lcccccccc}
\hline & \multicolumn{2}{c}{$\begin{array}{c}\text { Type of } \\
\text { Classroom }\end{array}$} & \multicolumn{2}{c}{ SRL } & \multicolumn{2}{c}{ Self-Efficacy } & \multicolumn{2}{c}{$\begin{array}{c}\text { Achievement } \\
\text { Antecedent }\end{array}$} \\
Predictors & Maths & Biology & \multicolumn{2}{c}{ Maths Biology } & Maths & Biology & Maths Biology \\
\hline Gender & $\mathrm{ns}$ & $\mathrm{ns}$ & $\mathrm{ns}$ & $-0.16^{*}$ & $0.12^{\wedge}$ & $\mathrm{ns}$ & $\mathrm{ns}$ & $\mathrm{ns}$ \\
$\mathrm{IQ}$ & $0.23^{*}$ & $0.22^{*}$ & $\mathrm{~ns}$ & $-0.16^{*}$ & $0.23^{*}$ & $\mathrm{~ns}$ & $\mathrm{~ns}$ & $0.21^{*}$ \\
Home Background & $-0.26^{*}$ & $-0.30^{*}$ & $\mathrm{~ns}$ & $\mathrm{~ns}$ & $\mathrm{~ns}$ & $\mathrm{~ns}$ & $-0.13^{\wedge}$ & $\mathrm{ns}$ \\
Home Practice & $0.18^{*}$ & $0.24^{*}$ & $0.22^{*}$ & $0.25^{*}$ & $\mathrm{~ns}$ & $\mathrm{~ns}$ & $\mathrm{~ns}$ & $\mathrm{~ns}$ \\
Extra Lesson & $-0.21^{*}$ & $-0.16^{*}$ & $\mathrm{~ns}$ & $\mathrm{~ns}$ & $\mathrm{~ns}$ & $\mathrm{~ns}$ & $\mathrm{~ns}$ & $\mathrm{~ns}$ \\
\hline
\end{tabular}

${ }^{*}$ considered significant if the standardised regression weight is $\geq 0.14$

${ }^{\wedge}$ considered significant marginally if the standardised regression weight is $0.10-0.13$ ns=not significant

na=not available due to no mediating variables being involved

Surprisingly, when other variables are taken into account, the level of scores of students in the Treatment Group is slightly lower in Mathematics Achievement than students in the Non-Treatment Group. Although TREATM is not significantly related to Mathematics Achievement, it is more likely that initially students in Non-Treatment Groups are seen to perform slightly better on the Mathematics tests initially administered at Time 1 than students in the Treatment Group after other factors are taken into consideration. Furthermore, students from lower status home backgrounds can be seen to do significantly better in Mathematics Achievement than students from higher status home backgrounds.

Table 3 shows that there are three variables that are significantly related to Biology Achievement. They are SCHOOL, $I Q$, and CLASSRMS. The roles of SCHOOL and CLASSRMS in Biology Achievement are similar to those for Mathematics Achievement. Students in SCHOOL1 perform better in Biology and Mathematics Achievement than students in SCHOOL2 and SCHOOL3. Students in accelerated classrooms achieve better in Mathematics and Biology than students in regular classrooms. IQ is a significant contributor to Biology Achievement but not to Mathematics Achievement. However, there is an indirect effect (0.09) of IQ operating to influence Mathematics Achievement through GENDER. IQ still makes a contribution to Mathematics Achievement although the coefficient is small and the effect is indirect. HOMBACK and SE significantly influence Mathematics Achievement but not Biology Achievement. However, there is a small negative influence $(-0.08)$ of HOMBACK on Biology achievement indicating that students from lower status homes are more likely to perform better in Biology Achievement, with the effect operating through IQ.

Effects of Student Characteristics. The discussion of the effects of student characteristics is based on the findings at the initial condition. In this case, the data obtained are before any intervention or treatment is conducted. The student characteristics involved in this study are gender, IQ, home background, home practice, and extra lessons. The effects of these student characteristics are presented in Table 4.

Effect of Student Characteristics on Type of Classrooms. It can be seen in Table 4 the student's characteristics, except Gender, have mostly small relationships with Type of Classrooms. It 
seems that students with higher IQ are more likely to be in accelerated classrooms than in regular classrooms. Students in accelerated classrooms are also more likely to do Home Practice than their classmates in regular classrooms. Moreover, it is recorded in Table 4 that the signs of the regression coefficients for Type of Classrooms regressed on Home Background and Extra Lessons are negative. From these estimated values, it can be concluded that students with lower parental status, and students who have fewer extra lessons outside the classroom are more likely to be in an accelerated classroom than in a regular classroom. These somewhat unexpected negative relationships appear to be a consequence of the fact that the scholarships in some schools (most likely SCHOOL2) are provided for very able students who come from lower status homes to attend school at this level in accelerated classrooms. Moreover, their lower status parents possibly cannot afford to pay for extra tuition.

Effect of Student Characteristics on Self-Regulated Learning. As noted in Table 4, Home Practice has a strong relationship with the use of Self-Regulated Learning Strategies in learning Mathematics and Biology. Students who are doing more Mathematics practice at home are more likely to have a higher level of use of Self-Regulated Learning strategies. Moreover, home practice is also related to Self-Regulated Learning in Biology, since for Self-Regulated Learning towards Biology, a positive relationship is recorded for Home Practice. Students who practise Biology at home are more likely to have a higher level of SelfRegulated Learning strategies in Biology. There are negative path relationships from Gender and IQ to Biology SelfRegulated Learning. It can be concluded that girls are more likely to have a higher level of use of Self-Regulated Learning strategies for Biology than boys, and students with a lower IQ are more likely to have a higher level of use of Self-
Regulated Learning strategies for Biology.

\section{Effect of Student Characteristics} on Self-Efficacy. It is shown in Table 4 that IQ has a significant positive path relationship for Self-Efficacy towards learning Mathematics. It appears that students with a higher IQ feel more selfefficacious towards learning Mathematics. Gender also has a positive path relationship for Mathematics Self-Efficacy, although it is only marginally significant. This is an indication that boys are likely to feel more efficacious towards learning Mathematics than girls. On the other hand, there are no relationships between students' characteristics and Self-Efficacy in Biology.

Effect of Student Characteristics on Academic Achievement. As can be seen in Table 4 , there is a negative marginal relationship between Home Background and Mathematics Achievement. It can be concluded that students who come from homes of lower status perform slightly higher on the Mathematics Achievement tests. For Biology Achievement, students with higher IQ are more likely to have a higher level of Biology Achievement.

Effects of Type of Classrooms. The following discussion presents the effects of Type of Classrooms on SelfRegulated Learning, Self-Efficacy, and Academic Achievement.

Effect of Type of Classrooms on Self-Regulated Learning (SRL). The Type of Classrooms variable in this study is associated with Accelerated Classrooms. One of the purposes of this study is to explore whether there is a direct relationship between Accelerated learning and the use of Self-Regulated Learning strategies. The standardised regression weights from Self-Regulated Learning regressed on Type of Classrooms is being in an Accelerated classroom is coded ' 1 ' and being in a Regular classroom is coded ' 0 '.

It is recorded in Table 5 that at the initial condition of this study, Accelerated 
Table 5. Regression Coefficients of Self-Regulated Learning regressed on Type of Classrooms

\begin{tabular}{ccccc}
\hline Time & \multicolumn{2}{c}{ Mathematics } & \multicolumn{2}{c}{ Biology } \\
& Direct & Indirect & Direct & Indirect \\
\hline 1 & 0.05 & na & $0.16^{*}$ & na \\
\hline
\end{tabular}

Table 6. Regression Coefficients of Self-Efficacy regressed on Type of Classrooms

\begin{tabular}{ccccc}
\hline Time & \multicolumn{2}{c}{ Mathematics } & \multicolumn{2}{c}{ Biology } \\
& Direct & Indirect & Direct & Indirect \\
\hline 1 & $-0.13^{\wedge}$ & 0.02 & $0.12^{\wedge}$ & 0.09 \\
\hline
\end{tabular}

${ }^{*}$ considered significant if the standardised regression weight is $\geq 0.14$

${ }^{\wedge}$ considered significant marginally if the standardised regression weight is $0.10-0.13$ ns=not significant

na=not available due to no mediating variables being involved

learning is positively related to SelfRegulated Learning in Biology but there is only a very weak relation in Mathematics. This can be stated in proposition as follow.

Proposition 1. Participation in an Accelerated program has initial direct effects on Self-Regulated Learning in both Mathematics and Biology learning.

Effect of Type of Classrooms on Self-Efficacy (SE). As mentioned earlier, the Type of Classrooms variable in this study is associated with Accelerated Classrooms. In addition, another purpose of this study is to examine whether there is a relationship between Accelerated learning and Self-Efficacy, either directly or indirectly. Table 6 presents the standardised regression weights of SelfEfficacy regressed on Type of Classrooms.

Type of Classrooms is associated with Accelerated learning and positively and marginally related to Self-Efficacy in Biology, but negatively and marginally related to Mathematics Self-Efficacy, possibly because Self-Efficacy is a relative idea based on each individual's judgment about his or her capability with respect to the other members of the group who form a frame of reference.
In an accelerated classroom there are some students who are very good at Mathematics who are high in mathematics Self-Efficacy, while the weaker students in the accelerated classroom probably consider that they are low in Mathematics Self-Efficacy compared with their classmates. This can be stated in proposition as follow.

Proposition 2. Participation in an Accelerated program has initial direct effects on Self-Efficacy in both Mathematics and Biology learning.

Effect of Type of Classrooms on Academic Achievement (ACH). As noted previously, the Type of Classrooms variable in this study is associated with Accelerated classrooms. In addition, another purpose of this study is to examine whether there is a relationship between Accelerated learning and Academic Achievement either directly or indirectly. Table 7 presents the standardised regression weights for Academic Achievement regressed on Type of Classrooms.

Table 7 records that, there is a significant relationship between Accelerated learning and Achievement. This can be stated in proposition as follow. 
Table 7. Regression Coefficients of Academic Achievement regressed on Type of Classrooms

\begin{tabular}{ccccc}
\hline Time & \multicolumn{2}{c}{ Mathematics } & \multicolumn{2}{c}{ Biology } \\
& Direct & Indirect & Direct & Indirect \\
\hline 1 & $0.20^{*}$ & -0.02 & $0.26^{*}$ & ns \\
\hline
\end{tabular}

Table 8. Regression Coefficients of Self-Efficacy regressed on Self-Regulated Learning

\begin{tabular}{ccccc}
\hline Time & \multicolumn{2}{c}{ Mathematics } & \multicolumn{2}{c}{ Biology } \\
& Direct & Indirect & Direct & Indirect \\
\hline 1 & $0.42^{*}$ & na & $0.54^{*}$ & na \\
\hline
\end{tabular}

Table 9. Regression Coefficients of Academic Achievement regressed on SelfRegulated Learning

\begin{tabular}{ccccc}
\hline Time & \multicolumn{2}{c}{ Mathematics } & \multicolumn{2}{c}{ Biology } \\
& Direct & Indirect & Direct & Indirect \\
\hline 1 & ns & 0.09 & Ns & ns \\
\hline
\end{tabular}

${ }^{*}$ considered significant if the standardised regression weight is $\geq 0.14$

${ }^{\wedge}$ considered significant marginally if the standardised regression weight is $0.10-0.13$

ns=not significant

na=not available due to no mediating variables being involved

Proposition 5c. Participation in an Accelerated program has initial direct effects on Academic Achievement in both Mathematics and Biology learning.

Effects of Self-Regulated Learning. The following section considers the effects of Self-Regulated Learning on Self-Efficacy and Academic Achievement.

Effects of Self-Regulated Learning on Self-Efficacy. Since the Treatment aims to have a direct influence on SelfRegulated Learning, it is also necessary to investigate whether or not there is a relationship between Self-Regulated Learning and Self-Efficacy. Table 8 records the regression coefficients for Self-Efficacy regressed on Self-Regulated Learning.

It is seen in Table 8 that Self-Regulated Learning has a significant influence on Self-Efficacy in both Mathematics and Biology. The result shows that there is a strong effect of Self-Regulated
Learning on Self-Efficacy. This can be stated in proposition as follow.

Proposition 4. Self-Regulated Learning has a direct effect on Self-Efficacy in both Mathematics and Biology learning.

Effects of Self-Regulated Learning on Academic Achievement. It is also necessary to investigate whether or not there is an effect of Self-Regulated Learning on Academic Achievement directly or indirectly. Table 9 records the regression effects of Academic Achievement regressed on Self-Regulated Learning. However, there are no significant direct effects and only recognisable indirect effects in the case of Mathematics learning.

It is shown in Table 9 that SelfRegulated Learning is not a significant predictor for either Mathematics or Biology Academic Achievement. However, there is a small indirect effect from Mathematics Self-Regulated Learning to 
Table 10. Regression Coefficients of Academic Achievement regressed on SelfEfficacy

\begin{tabular}{ccccc}
\hline Time & \multicolumn{2}{c}{ Mathematics } & \multicolumn{2}{c}{ Biology } \\
& Direct & Indirect & Direct & Indirect \\
\hline 1 & $0.22^{*}$ & na & ns & na \\
\hline
\end{tabular}

* considered significant if the standardised regression weight is $\geq 0.14$

$\wedge$ considered significant marginally if the standardised regression weight is $0.10-0.13$ ns=not significant

na=not available due to no mediating variables being involved

Mathematics Academic Achievement through Mathematics Self-Efficacy. Planning learning is largely unrelated to achievement. It involves planned effort and good and weak students can plan their work. The indirect effect associated with Mathematics learning implies that students who plan their work are also higher in Mathematics Self-Efficacy and this lifts their level of achievement.

These results show that: (a) there is no significant direct effect of Self-Regulated Learning on Academic Achievement either in Mathematics or Biology learning; but (b) there is an indirect effect of Self-Regulated Learning on Mathematics Academic Achievement that is mediated by Self-Efficacy; and These can be stated in propositions as follow.

Proposition 5. Self-Regulated Learning does not have a direct effect on Academic Achievement in either Mathematics or Biology learning.

Proposition 6. Self-Regulated Learning has an indirect effect on Academic Achievement in Mathematics that is mediated by Self-Efficacy in Mathematics learning. There is no corresponding effect for Biology learning.

Effects of Self-Efficacy. The following section considers the effects of SelfEfficacy on Academic Achievement.

Effects of Self-Efficacy on Academic Achievement. It is indicated above that there are no direct effects of SelfRegulated Learning on Academic Achievement. Consequently, this study also examines whether there is a direct relationship between Self-Efficacy and Academic Achievement, since it can be argued that there may also be an indirect effect of Self-Regulated Learning on Academic Achievement operating through Self-Efficacy. Table 10 presents the Regression Coefficients of Academic Achievement regressed on Self-Efficacy.

It can be seen in Table 10 that SelfEfficacy influences Mathematics Academic Achievement significantly but SelfEfficacy is not a significant factor that influences Biology Academic Achievement. Mathematics is a subject that students think they can or cannot do well with respect to performance on achievement tests. However, Biology is a subject that students can do well with effort irrespective of their perceived level of ability. The result shows that there is an effect of Self-Efficacy on Academic Achievement in Mathematics learning but not in Biology learning. This can be stated in proposition as follow.

Proposition 7. Self-Efficacy has a direct effect on Academic Achievement in Mathematics but not in Biology.

Summary of Result. The 7 propositions have been advanced from exploratory analyses that yield standardised regression coefficients, although metric coefficients are more appropriately used for comparisons between regression models. Moreover, the relatively crude significance tests, only in a general way, take into consideration the nested nature of the data. Consequently, more rigorous analytical procedures are necessary in 
Table 11. Summary of the Propositions

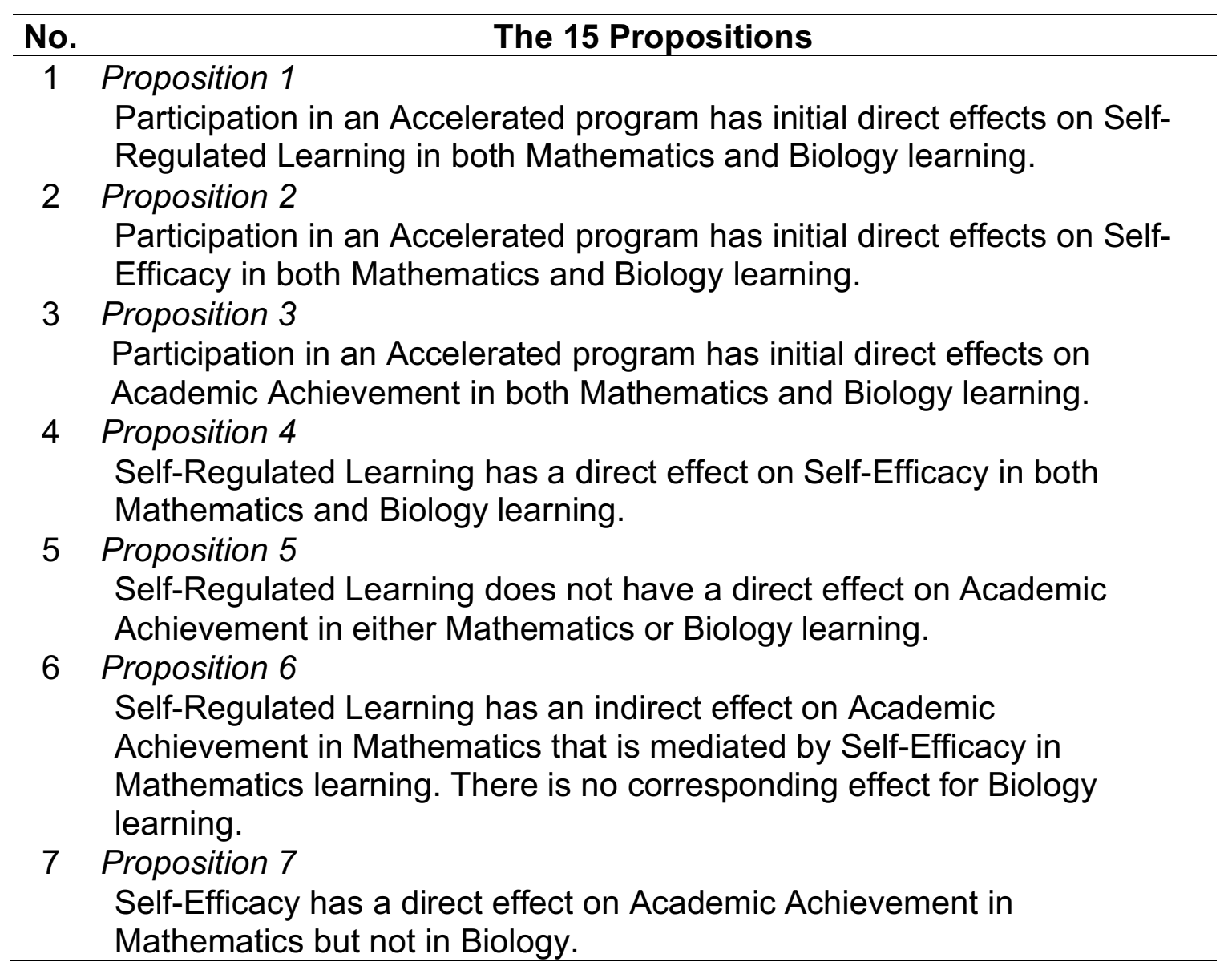

order to test more meaningfully these 7 propositions.

The results, in general, are highly similar for Mathematics and Biology. However, there are some differences between the processes of Mathematics and Biology learning. Self-Regulated Learning shows a significant relation to SelfEfficacy both in Mathematics and Biology. Self-Efficacy shows a relation to Mathematics Academic Achievement significantly, but does not significantly relate to Biology Academic Achievement. SelfRegulated Learning has an indirect influence on Mathematics Academic Achievement. The influence of Self-Regulated Learning on Mathematics Academic Achievement is through Self-Efficacy. Mathematics is a subject in which students perceive they can or cannot do well. It requires ability. Biology is a subject that all can do well with effort.
Accelerated learning is positively related to Self-Efficacy in Biology, but negatively in Mathematics, probably because Self-Efficacy is a relative idea. In accelerated classrooms there are some students who are very good at Mathematics with high levels of Self-Efficacy and the weaker students in accelerated classrooms appear to consider that they are low in Self-Efficacy compared with their classmates. After the intervention, some students who are low in Self-Efficacy in accelerated classrooms appear to rise in their Self-Efficacy and then the correlation becomes closer to zero.

The analyses using PLSPATH as an exploratory step lead to the major issues to be addressed in this study. Therefore, 7 propositions have been formulated to examine the relations among variables. The 7 propositions are presented in Table 11. 


\section{Discussion}

According to Weiner's attribution theory (Weiner, 1986), ability and effort were the dominant internal factors in school learning while task difficulty and luck were the most commonly identified external factors. From the high school students' point of view, membership of an accelerated classroom was sometimes perceived as a stressful learning condition, since these students were required to obtain high achievement but they had less time to learn and to develop social skills. The shortened period of study required students to complete more tasks during each school year.

Since the 2000 and 2001 academic year the term 'special education' has been extended by Indonesian Government to provide special education for students with high ability learning needs, well-known as academic gifted students, that was projected in giving approval to several schools to conduct an acceleration program by shortening the period of study. The issues of the employment of acceleration program have been raised from psychological to practical impacts. From high school students' point of view, membership in an accelerated classroom was perceived as a stressful learning condition, such as, they were required to obtain high achievement and in another case they had less time to develop social skills. As mention by Bandura (1995), there are three factors that students' efforts during learning: personal, behavioural, and environment factors. In this study, the personal factor included how they regulated themselves in learning and how they perceived their ability to master all materials stated in curriculum. The behavioural factor was projected in their academic achievement. The environment factor in this study covered the classrooms of students being put, that is, accelerated and regular classroom. This study proposed that academic achievement is influenced by self-regulated learning through the mediation of selfefficacy, which effort was more for the use of self-regulated learning strategies while ability was more in the self-efficacy. This study focused on Mathematics and Biology the main subjects taught at high school with different aspects. This research study is to understand the relationships between self-regulated learning, academic self-efficacy, and academic achievement in different type of classrooms, that is, accelerated and regular classrooms, and in specific subject areas, that is Mathematics and Biology, and the students' characteristics. This study reveals a number of significant differences between the processes of Mathematics and Biology learning, although there are several similarities for Mathematics and Biology learning.

The main variables in this study are Self-Regulated Learning and Self-Efficacy, that is based on Bandura's Social Cognitive theory, that function on both of them. It is widely found in research findings and literature that Self-Efficacy influences Self-Regulated Learning, however substantial findings are lacking for the reverse path that is Self-Regulated Learning influence Self-Efficacy. This study shows that Self-Regulated Learning shows a significant relation to Self-Efficacy, particularly in Mathematics and Biology learning. The influence of Self-Regulated Learning and Self-Efficacy on Academic Achievement could be direct or indirect. This study shows that there is no direct influence of Self-Regulated Learning on Academic Achievement, but in part there is a direct influence of Self-Efficacy on Mathematics Academic Achievement.

The strength of this study is explored in the models of the relationships between process variables in influencing academic achievement in Mathematics and Biology with the inclusiveness of type of classrooms and controlled statistically by schools. Employing path analysis using the partial least square path (PLSPATH). Path analysis is conducted using analysis of moment structure. The examination using analysis of moment 
structure assesses at a single level, that is, student-level.

\section{Conclusion}

The results, in general, are highly similar for Mathematics and Biology both initially and over time while there are some significant differences between the processes of Mathematics and Biology learning. The Accelerated program has a direct effect on Self-Regulated Learning for Mathematics and Biology learning. However, further examination shows that the Accelerated program has a direct effect on Self-Regulated Learning for Biology learning. Membership of an Accelerated program leads to a higher level of regulation in Biology learning. the Accelerated program has a direct effect on SelfEfficacy for Mathematics and Biology learning. Accelerated program is related to Self-Efficacy in Biology over time, but the relation disappears in Mathematics. In Accelerated classrooms there are some students who are very good at Mathematics with high levels of Self-Efficacy and students who are low in Mathematics in Accelerated classrooms appear to consider that they are low in Self-Efficacy compared with their classmates because Self-Efficacy is a relative idea that can be changed upon the situation. However, in further examination the Accelerated program has a direct effect on Self-Efficacy for Mathematics learning. Membership of an Accelerated program leads to a higher level of 'can do' in Mathematics learning. The relationships between Accelerated Program and Achievement occur over time. In general, students in the Accelerated Program perform better than students in the Regular Program. Membership of an Accelerated program leads to higher levels of performance in both Mathematics and Biology. Self-Regulated Learning shows a significant relation to Self-Efficacy both in Mathematics and Biology learning. Regulation in learning leads to a higher level of 'can do' on both Mathematics and Biology tests. SelfEfficacy shows a relation to Mathematics
Academic Achievement significantly, but does not significantly relate to Biology Academic Achievement. A 'can do' attitude leads to a higher level of performance in Mathematics. Self-Regulated Learning has an indirect influence on Mathematics Academic Achievement. The influence of Self-Regulated Learning on Mathematics Academic Achievement is mediated through Self-Efficacy. Mathematics is a subject in which students perceive they can or cannot do well. It requires ability. Biology is a subject that all can do well with effort. Planning learning is largely independent of Achievement, it is related to planned effort and good and weak student can plan their work.

Limitation of Study. The research findings were limited to some extent. (a) The data in this study were based on students' reported use of self-regulated learning and students' reported on selfefficacy. (b) The study has only involved participants in the first year of high school. (c) The study has only focused two specific subjects taught at high school that is mathematics and biology. (d) The issue of generalisation was not addressed in this study since all the participants in this study were high school students in Jakarta.

\section{References}

Antara News (5 July 2010). Kelas akselerasi ganggu masalah sosial siswa. Retrieved Augustus 17, 2018 from https://www.antaranews.com/berita/ 210419/kelas-akselerasi-ganggumasalah-sosial-siswa

Bandura, A. (1997). Self-efficacy: The exercise of control. New York: W.H. Freeman and Company.

Bandura, A. (1995). Exercise of personal and collective efficacy in changing societies. In A. Bandura (Ed.), Selfefficacy in changing societies. New York: Cambridge University Press. 
Bandura, A. (1986). Social foundations of thought and action. New York: Prentice Hall.

Bandura, A. (in press). Guide for constructing self-efficacy scales. In Pajares, F., \& Urdan, T. (Eds.). Adolescence and education, Vol. 4: self-efficacy beliefs of adolescents. Greenwich, CT: Information Age Publishing.

Bong, M., \& Skaalvik, E.M. (2003). Academic self-concept and self-efficacy: How different are they really? Educational Psychology Review, 15(1), 1-40.

Graham, S. (1991). A review of attribution theory in achievement contexts. Educational Psychology Review, 3(1), 5-39. doi: 10.1007/bf01323661

Keeves, J. P. (1988). Path analysis. In J. P. Keeves (Ed.), Educational research, methodology, and measurement: An international handbook. Oxford: Pergamon.

Gredler, M. E. (2001). Learning and instruction: Theory into practice, 4th ed. Upper Saddle River: Merrill Prentice Hall.

Kirby, J. R. (1984). Strategies and processes. In J. R. Kirby (Ed.), Cognitive strategies and educational performance. Orlando, Florida: Academic Press, Inc.

Kish, L. (1987). Statistical design for research. New York: John Wiley \& Sons.

Kline, R. B. (2005). Beyond significance testing: Reforming data analysis methods in behavioural research. Washington, DC: American Psychological Association.

Kompas Cetak (2004). Retrieved from http://64.203.71.11/kompascetak/04 07/23/humaniora/1165710.htm

Kompas (15 August 2004). Mereka memang membanggakan, tetapi..., Retrieved April 18, 2006, from http://www.kompas.com/kesehatan/ news/0408/15/ 220038.htm

Kompas (30 May 2002). Kelas akselerasi sebenarnya tidak dianjurkan lagi,
Retrieved May 26, 2004, from http://www.kompas.com/kompascetak/0205/30/dikbud/kela09.htm

Kusumawardhani, D. E. (2000). Students' conception of learning and learning motivation in acceleration and regular class (research conducted in SMU Negeri 8 Jakarta and SMU LabSchool Jakarta). (Unpublished Master thesis). Jakarta: Faculty of Psychology, University of Indonesia.

Lorsbach, A. W., \& Jinks, J. L. (1999). Self-efficacy theory and learning environment. Learning Environments Research, 2, 157-167.

Pedhazur, R. J. (1997). Multiple regression in behavioral research: explanation and prediction, 3rd Ed. New York: Holt, Rinehart, and Winston.

Pintrich, P. R., \& De Groot, E. V. (1990). Motivated and self-regulated learning components of classroom academic performance. Journal of Educational Psychology, 82(1), 33-40. doi: 10.1037/0022-0663.82.1.33

Republika (14 October 2009). Kemendikbud hapus program akselerasi. Retrieved Augustus 17, 2018, from https://www.republika.co.id/berita/ko ran/Didaktika/14/10/09/nd6cab10kemendikbud-hapus-programakselerasi

Schloemer, P., \& Brenan, K. (2006). From students to learners: Developing self-regulated learning. Journal of Education for Business, 82(2), 8187. doi: 10.3200/joeb.82.2.81-87

Schneider, B. H., Clegg, M. R., Byrne, B. M., Ledingham, J. E., \& Crombie, G. (1989). Social relations of gifted children as a function of age and school program. Journal of Educational Psychology, 81(1), 48-56. doi: 10.1037/0022-0663.81.1.48

Sellin, N. (1995). Partial least squares modeling in research on educational achievement. In R. H. Lehmann (Ed.), Reflections on educational achievement: Papers in honour of $T$. 
Neville Postlethwaite (pp. 256-267). New York: Waxmann.

Sellin, N. (1989). PLSPATH Version 3.01[Statistical software]. Hamburg, West Germany.

Sistem Pendidikan Nasional (1989)

Sherer, M., Maddux, J. E., Mercandante, B., Prentice-Dunn, S., Jacobs, B., \& Rogers, R. W. (1982). The selfefficacy scale: Construction and validation. In R. B. Ammons \& C. H. Ammons, Psychological Reports, 51, 663-671.

Stipek, D. J. (2002). Motivation to Learn: Integrating Theory and Practice. Boston, MA: Allyn \& Bacon.

Van Tiel, J. M. (2007). Tinggalkan Kelas Akselerasi, Masuk Kelas Inklusi. Retrieved February 14, 2008, from http://www.sinarharapan.co.id/berita /0702/09/ipt02.html

Weiner, B. (1986). Attribution, emotion, and action. In R. M. Sorrentino \& E. T. Higgins (Eds.), Handbook of motivation and cognition: Foundations of social behavior (pp. 281312). New York, NY, US: Guilford Press.

Winne, P. H., \& Perry, N. E. (2000). Measuring self-regulated learning. In: M. Boekaerts, P. R. Pintrich, \& M. Zeidner (Eds.), Handbook of selfregulation (pp. 532-564). San Diego: Academic Press, San Diego (2000).

Wold, H. (1982). Soft modelling: The basic design and some extensions.
In H. Wold (Ed.), Systems under indirect observation part II. Amsterdam: Noth Holland Press.

Wood, R. E., \& Locke, E. A. (1987). The relation of self-efficacy and grade goals to academic performance. Educational and Psychological Measurement, 47, 1013-1024. doi:

Woolfolk, A. E. (1998). Educational psychology. Boston: Allyn and Bacon

Zimmerman, B. J. (2001). Theories of self-regulated learning and academic achievement: An overview and analysis. In B. J. Zimmerman \& D. H. Schunk (Eds.), Self-regulated learning and academic achievement: Theoretical perspective, 2nd Ed, (pp. 1-37). Mahwah, NJ: Lawrence Erlbaum Associates.

Zimmerman, B. J., \& Martinez-Pons, M. (1990). Student differences in selfregulated learning: Relating grade, sex, and giftedness to self-efficacy and strategy use. Journal of Educational Psychology, 82, 51-59. doi: 10.1037/0022-0663.82.1.51

Zimmerman, B. J., \& Martinez-Pons, M. (1986). Development of a structural interview for assessing student use of self-regulated learning strategies. American Educational Research Journal, 23(4), 614-628. doi: $10.2307 / 1163093$ 